\title{
RELIABILITY ASSESSMENT OF EXISTING STRUCTURES
}

\section{HODNOCENÍ SPOLEHLIVOSTI EXISTUJÍCÍCH KONSTRUKCÍ}

\author{
Marková Jana \\ Czech Technical University in Prague, Klokner Institute, \\ 16608 Prague 6, Czech Republic \\ e-mail: markova@klok.cvut.cz
}

\begin{abstract}
The international standard ISO 13822 provides procedures for the reliability assessment of existing structures including the application of probabilistic methods. Probabilistic approach facilitates to decide about new exploitation of existing structures. Application of probabilistic methods for the reliability assessment of existing structures is shown on the example of deteriorated balcony beams.
\end{abstract}

Keywords: existing structures, assessment, probabilistic methods, reliability index

Streszczenie: Mezinárodní norma ISO 13822 uvádí postupy pro hodnocení spolehlivosti existujících konstrukcí včetně použití pravděpodobnostních metod. Pravděpodobnostní přístupy umožňují rozhodnout o novém využití existujících konstrukcí. Použití pravděpodobnostních metod pro hodnocení spolehlivosti existujících konstrukcí je uvedeno na příkladě degradujících balkónových nosníků.

Slowa kluczowe: existující konstrukce, hodnocení, pravděpodobnostní metody, index spolehlivosti 


\section{RELIABILITY ASSESSMENT OF EXISTING STRUCTURES}

\section{Introduction}

EN Eurocodes, presently being implemented into the system of national standards nearly in the whole Europe, are particularly intended for the design of new structures. Supplementary rules for the verification of existing structures are still missing. General requirements and procedures for the assessment of existing structures based on the theory of structural reliability are provided in ISO 13822 [1]. For the application of this standard in building practice in the Czech Republic, six National annexes were developed. Selected provisions and new terms including material independent problems for the assessment of existing structures are explained in the first Annex NA. Testing of existing structures and materials, and also principles of experimental evaluation are introduced in the National Annex NB. Material oriented Annexes NC to NF provide recommendation for determination of material properties for reinforced concrete, steel, timbre, composites and masonry including tables for conversion among existing and presently valid classes of concrete.

\section{Reliability assessment of existing structures}

The design of existing structures is as a rule based on different approaches given in the original standards, including the method of allowable stresses or the safety factor method. If the structure is designed by means of the partial factor method, then the procedures for determining the characteristic and design values of basic variables, the rules for load combinations and analytical models commonly differ from provisions given in current standards. For reliability analyses of structures, the partial factor method or probabilistic methods may be applied according to ISO 13822 [1].

\subsection{Partial factor method}

The partial factor method represents the basic method in new European and international standards. The values of partial factors for actions and material 
properties are recommended on the basis of calibrations and good practice in construction. The required reliability level of a structure could be considered for determining the values of partial factors. For the 50 years design working life of a structure and ultimate limit state, the target value of reliability index $\beta_{\mathrm{t}}=3,8$ is commonly recommended (for the reliability class RC 2 according to EN 1990 [2]). Where justifiable, other requirements for the target reliability index may be considered for existing structures than for new ones. The partial factors for existing structures could be in those cases modified.

\subsection{Probabilistic methods}

The probabilistic methods may be in specific cases, e.g. in time dependent problems, applied with advantage for the verification of existing structures or for the assessment of residual lifetime. For the probabilistic analysis of existing structures, the limit state function $\mathrm{g}(\boldsymbol{X})$ is specified for the vector $\boldsymbol{X}$ of basic variables. It is assumed that the structure is reliable for the condition $\mathrm{g}(\boldsymbol{X})>0$. The failure probability $P_{\mathrm{f}}$ is determined on the basis of integration over region $Z(X)<0$, where the structure is not reliable, given as

$P_{\mathrm{f}}=\int_{\mathrm{Z}(X)<0} \varphi_{X}(\boldsymbol{x}) \mathrm{d} \boldsymbol{x}$

where $\varphi_{X}(\boldsymbol{x})$ is the joint probability density for the realisation of vector $\boldsymbol{x}$. Another reliability indicator is the generalized reliability index $\beta$ defined on the basis of the failure probability $P_{\mathrm{f}}$ as $\beta=-\Phi^{-1}\left(P_{\mathrm{f}}\right)$, where $\Phi$ is the standardised normal distribution function. Resulting failure probability $P_{\mathrm{f}}$ or reliability index $\beta$ of the structural member is compared with the target probability $P_{\mathrm{f}, \mathrm{t}}$ or target reliability index $\beta_{\mathrm{t}}$.

\section{Partial factors for required reliability level}

The concept of design values may be used for determining the partial factors of the basic variables applied for the verification of existing structures. The partial factors $\gamma_{i}$ for the basic variables $X_{i}$ having a favourable effect on structural reliability (resistance) may be determined as

$\gamma_{i}=x_{i \mathrm{k}} / x_{i \mathrm{~d}}$ 
where the values of partial factors $\gamma_{i}$ are commonly greater than one. The procedure for applying the partial factors based on expression (4) for the reliability assessment of existing structures is described as follows. The structural resistance $R$ (e.g. concrete strength, yield strength of steel) may be often described by two-parametric lognormal distribution. The characteristic value of resistance is commonly defined as $5 \%$ lower fractile. The partial factor $\gamma_{R}$ is according to expression (2) given as

$\gamma_{R}=\exp \left(-1,645 V_{R}\right) / \exp \left(-\alpha_{R} \beta V_{R}\right)$

where $V_{R}$ is the coefficient of variation for resistance $R$ and $\beta$ the required reliability index (e.g. target value), the coefficient 1,645 is the value of $5 \%$ fractile of the standardised normal distribution and the sensitivity factor $\alpha_{R}$ $=0,8$. The partial factor for resistance $\gamma_{R}$ versus the coefficient of variation $V_{R}$ for three reliability classes RC1 to RC 3 is illustrated in Fig. 1.

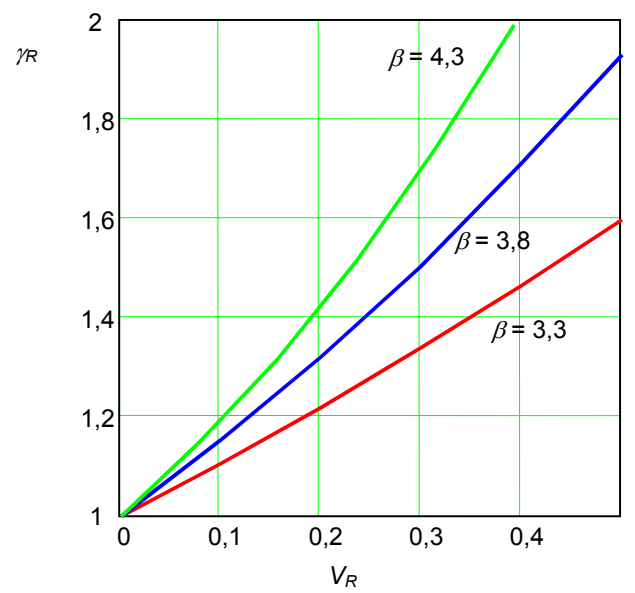

Fig. 1. The partial factor for resistance $\gamma_{R}$ versus the coefficient of variation $V_{R}$

For the coefficient of variation $V_{R}=0,1$ and structure of a common class $\mathrm{CC} 2$, the partial factor of resistance should be about $\gamma_{R}=1,15$. However, the direct application of results illustrated in Fig. 1 may be rather difficult because the characteristic value of material strength of a building material like steel corresponds in reality to lower probability than $5 \%$ given in EN 1990 [2]. This fact is due to the effort to increase the production quality of materials leading to increase the mean of the strength of real production. 


\section{An example of reliability assessment according to ISO 13822}

The procedure for the reliability assessment of existing structures is shown on a selected example of deteriorated balcony beams of panel houses in the North part of the Czech Republic. The Klokner Institute investigated 230 balconies of panel houses (construction system T0-6B-BTS). Detailed visual inspection proved that the reinforcement of concrete slabs was strongly affected by corrosion due to deteriorated insulation. The carbonation of concrete was visible particularly in front parts of balconies. Results of inspection revealed that the beams were made from concrete of class C 16/20 and reinforcement S 200 with diameter $0,008 \mathrm{~m}$. The beams were cantilevered $0,90 \mathrm{~m}$, their width $3,50 \mathrm{~m}$. The actual position of reinforcement considerably differed from assumptions made in the original design (concrete cover $0,01 \mathrm{~m}$, bar spacing $0,15 \mathrm{~m}$ ). The distribution of concrete cover $c$ for all 4890 measurements is shown in Figure 2. The actual concrete cover, varying from $0,002 \mathrm{~m}$ to $0,065 \mathrm{~m}$, did not provide adequate protection against adverse environmental influences and considerably decreased the load-bearing capacity of balcony components. The quality of construction work was very poor.

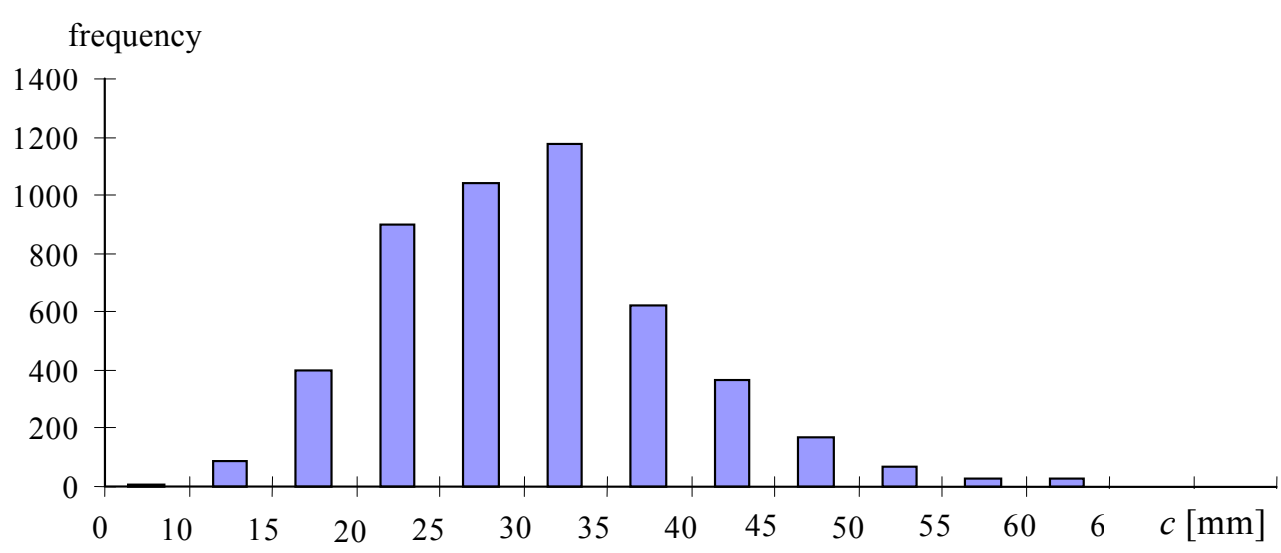

Fig. 2. Distribution of concrete cover $c$ for 230 balconies (4890 measurements, mean $\mu=0,026 \mathrm{~m}$, standard deviation $\sigma=0,009 \mathrm{~m}$, skewness $\alpha=0,58$ )

\subsection{Verification of balconies according to partial factor method}

The verification of beams based on the partial factor method according to ČSN 731201 [3] reveals that the design resistance of a beam $M_{R \mathrm{~d}}=$ $6,0 \mathrm{kNm}$ is greater than the design load effects $M_{E \mathrm{~d}}=3,15 \mathrm{kNm}$ on $1 \mathrm{bm}$ of a beam. In case that the reduction of the area of reinforcement due to 
corrosion and its actual position is considered, the condition $M_{R \mathrm{~d}}>M_{E \mathrm{~d}}$ may not be fulfilled yet. The results of analysis for three reinforcement areas $A_{\mathrm{s}}$ are shown in Fig. 3 (for design area $A_{\mathrm{s} 1}=100 \%$ and reduced areas $A_{\mathrm{s} 2}=$ $90 \%$ and $A_{\mathrm{s} 3}=75 \%$ ). The design action effect $M_{E \mathrm{~d}}$ is also illustrated.

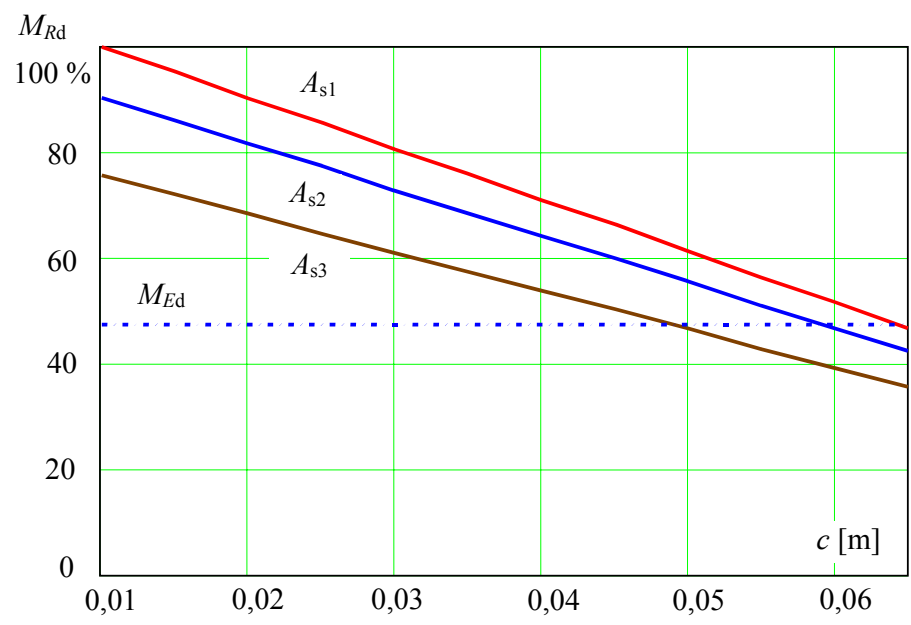

Fig. 3. The variation of resistance moment $M_{R \mathrm{~d}}$ with increasing concrete cover $c$ for 3 study cases of reinforcement $A_{\mathrm{s}}$ (for design area $A_{\mathrm{s} 1}=100 \%$ and reduced $A_{\mathrm{s} 2}=90 \%, A_{\mathrm{s} 3}=75 \%$ ).

\subsection{Probabilistic reliability analysis}

For the reliability analysis of balcony, the probabilistic approach according to ISO 13822 [1] is applied. The limit state function for the verification of balconies is given as

$g=\theta_{R} n\left(\pi \phi^{2} / 4\right) f_{\mathrm{y}}\left[h-c-\phi / 2-0,5 n\left(\pi \phi^{2} / 4\right) f_{\mathrm{y}} / f_{\mathrm{c}}\right]-\theta_{E}(g+p) L^{2} / 2$

where all applied basic variables are listed in Table 1 including relevant probability distributions. The probabilistic models of basic variables are based on the provisions of Probabilistic Model Code [4] of the research organisation JCSS and evaluations of test results.

The impact of reduced reinforcement area $\Delta A_{\mathrm{S}}$ on the reliability index $\beta$ for 4 cases of concrete cover $c$ (according to evaluated measurements of individual balconies) is illustrated in Fig. 4. Significant basic variable influencing the reliability of balcony beams is the concrete cover of 
reinforcement. In case the reduction of the area of reinforcement $\Delta A_{\mathrm{s}}$ is not taken into account, then the reliability index $\beta$ is decreasing from 5,2 to 3,7 for increasing concrete cover from 0,01 to $0,03 \mathrm{~m}$.

Table 1 Probabilistic models of basic variables

\begin{tabular}{|l|c|c|c|c|c|}
\hline Basic variable & $\begin{array}{c}\text { Sym- } \\
\text { bol }\end{array}$ & $\begin{array}{c}\text { Distrib } \\
\text { ution }\end{array}$ & $\begin{array}{c}\text { Dimens } \\
\text { ion }\end{array}$ & $\begin{array}{c}\text { Mean } \\
\mu\end{array}$ & $\begin{array}{c}\text { Standard } \\
\text { deviation }\end{array}$ \\
\hline Compr. concrete strength & $f_{\mathrm{c}}$ & $\mathrm{LN}$ & $\mathrm{MPa}$ & 24 & 4 \\
Yield strength & $f_{\mathrm{y}}$ & $\mathrm{LN}$ & $\mathrm{MPa}$ & 240 & 15 \\
\hline Length of the balcony & $L$ & $\mathrm{DET}$ & $\mathrm{m}$ & 0,90 & - \\
Diameter of a bar & $\phi$ & $\mathrm{DET}$ & $\mathrm{m}$ & 0,008 & - \\
Number of bars per balcony & $n$ & $\mathrm{DET}$ & - & 20 & - \\
Balcony depth in embedment & $h$ & $\mathrm{LN}$ & $\mathrm{m}$ & 0,12 & 0,01 \\
Concrete cover & $c$ & $\mathrm{BET}$ & $\mathrm{m}$ & 0,026 & 0,009 \\
\hline Uncertainty of resistance & $\theta_{R}$ & $\mathrm{LN}$ & - & 1,1 & $0,05 \mu$ \\
Uncertainty of load effect & $\theta_{E}$ & $\mathrm{LN}$ & - & 1 & 0,05 \\
\hline Density of concrete & $\rho$ & $\mathrm{N}$ & $\mathrm{MN} / \mathrm{m}^{3}$ & nom. & 0,06 \\
Imposed load & $p$ & $\mathrm{GAM}$ & $\mathrm{MN} / \mathrm{m}^{2}$ & 0,0008 & 0,00048 \\
\hline
\end{tabular}

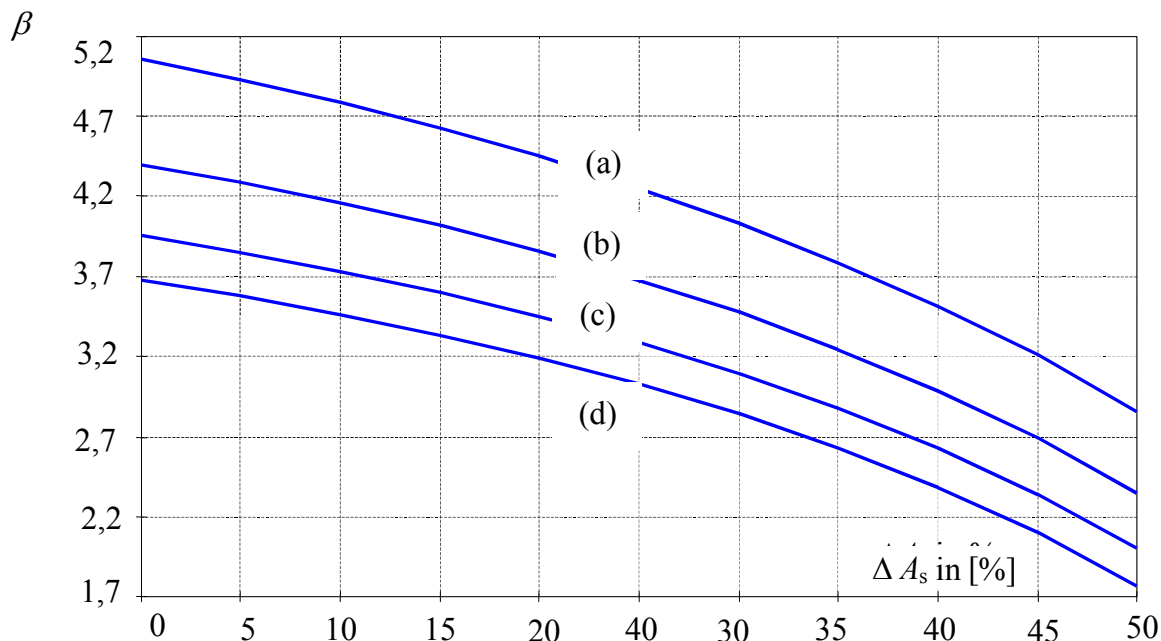

Fig. 4. Reliability index $\beta$ versus the reduction of reinforcement $\Delta A_{\mathrm{s}}$ (in \%) for four cases of cover $c$ : (a) mean $\mu=0,01 \mathrm{~m}$, (b) $0,02 \mathrm{~m}$, (c) $0,026 \mathrm{~m}$, (d) $0,03 \mathrm{~m}$ (coefficient of variation $V=0,35$, lower bound $a=0$, upper bound $b=3 \mu$, Beta distribution). 
The original design of balconies was consistent with requirements of standards valid in that time. Low-quality production of prefabricated balcony beams including poor quality of construction work on site was leading to significant reduction of the area of reinforcement considered in the original design. The significant basic variable influencing the reliability indices of balconies are the area of reinforcement and concrete cover. The reliability indices considerably decrease with decreasing area of reinforcement due to the corrosion (the index $\beta$ is reduced to one-half with $50 \%$ reduction of the reinforcement area).

\section{Influence of partial factors}

The design of existing balconies was influenced by values of partial factors and detailing given in the original Czech standards for structural design (recommended partial factors for permanent and variable actions $\gamma_{G}=1,1$, $\gamma_{Q}=1,3$, concrete cover $c=0,01 \mathrm{~m}$ ). Eurocodes recommend for the verification of the ultimate limit states (type STR) in most cases greater values of partial factors for actions $\left(\gamma_{G}=1,35, \gamma_{Q}=1,5\right)$ than ČSN. Fig. 4 indicates the variation of the initial reliability index $\beta$ (without any reduction of the reinforcement area due to rusting or negligence) with partial factors $\gamma_{G}$ and $\gamma_{Q}$ for a balcony component, assuming that these were applied in the design of a balcony. The reliability level $\beta_{\mathrm{t}}=3,8$ recommended in Eurocodes is shown in Fig. 5 by a white area.

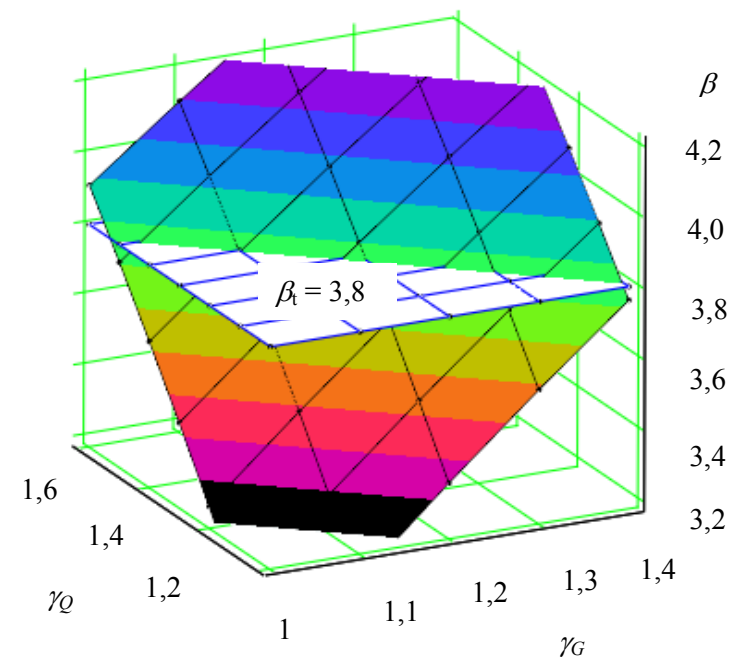

Fig. 5. Variation of the reliability index $\beta$ with partial factors $\gamma_{G}$ and $\gamma_{Q}$ 


\section{Conclusions}

The international standard ISO 13822 provides procedures for the reliability assessment of existing structures including the application of probabilistic methods. Probabilistic approach according to this standard facilitates to decide about new exploitation of existing structures. Application of probabilistic methods for the reliability assessment of existing structures is shown on the example of deteriorated balcony beams. Despite the design of beams fulfilled the requirements of originally applied standards, the low quality of production and adverse effects of environment caused significant reduction of reliability level of balconies and evoked the need for their repair. Detailed investigation revealed that the initial reliability index $\beta$ was in a range from 5,2 to 3,7 for individual beams. When reduced area of reinforcement due to corrosion was considered, the reliability index $\beta$ was further significantly decreasing.

Acknowledgement This research has been conducted in the Klokner Institute of the Czech Technical University in Prague, Czech Republic as a part of the project No. 103/06/1521 "Reliability and risks of structures in extreme conditions" supported by the Grant Agency of the Czech Republic.

\section{References}

1. ISO 13822, Assessment of existing structures, 2003.

2. EN 1990, Bases of structural design, CEN, 2002.

3. ČSN 73 1201, Navrhování betonových konstrukcí (Design of concrete structures), ČNI, 1986.

4. Probabilistic Model Code, Parts 1 to 4, Basis of design, Load and resistance models, Examples, JCSS, 2002. 


\section{HODNOCENÍ SPOLEHLIVOSTI EXISTUJÍCÍCH KONSTRUKCÍ}

\section{1. Úvod}

EN Eurokódy, které se nyní zavádějí do soustavy národních norem téměř $\mathrm{v}$ celé Evropě, jsou určeny zejména pro navrhování nových konstrukcí, chybí zde doplňující pokyny pro ověřování existujících konstrukcí. ISO 13822 [1] poskytuje obecné požadavky a postupy pro hodnocení existujících konstrukcí, které vycházejí ze zásad teorie spolehlivosti konstrukcí. Pro možnost aplikace této normy $\mathrm{v}$ praxi se $\mathrm{v}$ C̆R připravilo šest národních prríloh NA až NF. Příloha NA vysvětluje vybrané pokyny, nové termíny a zabývá se obecnými, materiálově nezávislými otázkami hodnocení spolehlivosti existujících konstrukcí. Příloha NB uvádí zkoušky existujících konstrukcí a materiálů a zásady jejich experimentálního ověřování. Př́lohy NC až NF jsou materiálově zaměřené, poskytují doporučení pro určení vlastností železobetonu, oceli, dřeva a zdiva u existujících konstrukcí, včetně převodních tabulek mezi existujícími a nyní platnými třídami betonů.

\section{Hodnocení spolehlivosti existujících konstrukcí}

Existující konstrukce byly navrženy podle různých předpisů, které doporučují různé metodické postupy navrhování včetně metody dovolených namáhání a stupně bezpečnosti. Pokud se tyto konstrukce navrhly metodou dílčích součinitelů, pak se postupy pro stanovení charakteristických a návrhových hodnot materiálových vlastností a zatížení, kombinace zatížení i použité výpočetní modely zpravidla liší od postupů podle nových evropských a mezinárodních norem. ISO 13822 [1] umožňuje při ověřování spolehlivosti existujících konstrukcí používat metodu dílčích součinitelů nebo pravděpodobnostní postupy.

\subsection{Metoda dílčích součiniteli̊}

Základní metodou pro ověřování spolehlivosti existujících konstrukcí je metoda dílčích součinitelů, uvedená v Eurokódech a v mezinárodních normách ISO. Doporučené hodnoty dílčích součinitelů zatížení a materiálových vlastností jsou stanoveny na základě kalibrací, porovnáním s původními normami a použitím pravděpodobnostních metod. Při stanovení hodnot dílčích součinitelů lze vycházet $\mathrm{z}$ požadavku na určitou úroveň 
spolehlivosti konstrukcí. V obvyklých př́padech se pro běžnou padesátiletou životnost konstrukce a mezní stavy únosnosti doporučuje směrná hodnota indexu spolehlivosti $\beta_{\mathrm{t}}=3,8$ (pro trrídu spolehlivosti RC2 podle [2]). Pokud to lze zdůvodnit, je $\mathrm{v}$ některých př́padech možné při ověřování existující konstrukce uvažovat jiný požadavek na směrnou hodnotou indexu spolehlivosti než u nové konstrukce. Dílčí součinitele pro existující konstrukce by se $\mathrm{v}$ těchto prípadech mohly upravit tak, aby tuto skutečnost zohledňovaly.

\subsection{Pravděpodobnostní metody}

Při působení časově proměnných vlastností základních veličin je někdy výhodné pro ověřování spolehlivosti existující konstrukce nebo návrhu její obnovy použít pravděpodobnostní metody. Při pravděpodobnostním rozboru spolehlivosti konstrukce se sestavuje funkce mezního stavu $\mathrm{g}(\boldsymbol{X})$ pro vektor $\boldsymbol{X}$ základních veličin. Předpokládá se, že konstrukce je spolehlivá, pokud platí nerovnost $\mathrm{g}(\boldsymbol{X})>0$. Pravděpodobnost poruchy $P_{\mathrm{f}}$ se stanoví integrací přes oblast $\mathrm{g}(\boldsymbol{X})<0$, ve které je konstrukce nespolehlivá, ze vztahu

$$
P_{\mathrm{f}}=\int_{\mathrm{Z}(X)<0} \varphi_{X}(\boldsymbol{x}) \mathrm{d} \boldsymbol{x}
$$

kde $\varphi_{X}(\boldsymbol{x})$ je sdružená hustota pravděpodobnosti pro realizaci vektoru $\boldsymbol{x}$. Dalším ukazatelem spolehlivosti konstrukce je index spolehlivosti $\beta$, který se definuje na základě pravděpodobnosti poruchy $P_{\mathrm{f}}$ vztahem $\beta=-\Phi^{-1}\left(P_{\mathrm{f}}\right)$, kde $\Phi$ označuje distribuční funkci normovaného normálního rozdělení. Vypočtená pravděpodobnost poruchy $P_{\mathrm{f}}$ nebo index spolehlivosti $\beta$ nosného prvku se porovnává se směrnou hodnotou pravděpodobnosti $P_{\mathrm{f}, \mathrm{t}}$ popr.. $\beta_{\mathrm{t}}$.

\section{Dílčí součinitele pro požadovanou úroveň spolehlivosti}

Koncepce návrhových hodnot lze použít pro stanovení dílčích součinitelů základních veličin, které se použijí pro ověření existujících konstrukcí. Dílčí součinitele spolehlivosti $\gamma_{i}$ se u základních veličin $X_{i}$, které mají př́znivý vliv na spolehlivost konstrukce (veličiny odolnosti), stanoví ze vztahu

$\gamma_{i}=x_{i \mathrm{k}} / x_{i \mathrm{~d}}$

kde $x_{i \mathrm{k}}$ je charakteristická a $x_{i \mathrm{~d}}$ návrhová hodnota vlastnosti materiálu nebo odolnosti konstrukce. Odolnost konstrukce $R$ (pevnost betonu, mez kluzu výztuže) se často popisuje dvouparametrickým lognormálním rozdělením 
s počátkem v nule. Charakteristická hodnota odolnosti se v EN 1990 [3] definuje jako dolní kvantil odpovídající pravděpodobnosti $5 \%$. Pro dílčí součinitel odolnosti $\gamma_{R}$ lze podle vztahu (2) zapsat

$\gamma_{R}=\exp \left(-1,645 V_{R}\right) / \exp \left(-\alpha_{R} \beta V_{R}\right)$

kde $V_{R}$ je variační koeficient odolnosti $R$ a $\beta$ požadovaný index spolehlivosti, součinitel 1,645 je hodnota $5 \%$ kvantilu normované náhodné veličiny $\mathrm{s}$ normálním rozdělením a součinitel citlivosti $\alpha_{R}=0,8$ [3]. Závislost hodnoty dílčího součinitele odolnosti $\gamma_{R}$ na variačním koeficientu $V_{R}$ pro tři třídy spolehlivosti konstrukcí RC1 až RC3 je uvedena na obr. 1 .

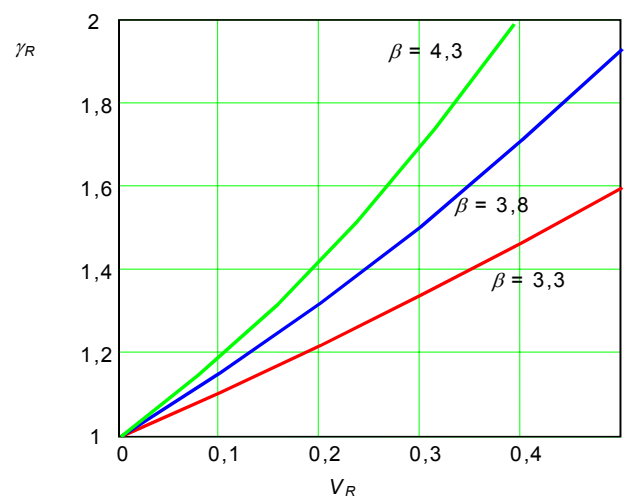

Obr. 1. Dílčí součinitel odolnosti $\gamma_{R} \mathrm{~V}$ závislosti na variačním koeficientu $V_{R}$

$\mathrm{Z}$ obr. 1 je patrné, že pro konstrukci v běžné třídě následků $\mathrm{CC} 2$ a pro variační koeficient $V_{R}=0,10$ by dílčí součinitel odolnosti měl mít hodnotu asi $\gamma_{R}=1,15$. Př́ímé použití výsledků uvedených na obr. 1 znesnadňuje skutečnost, že charakteristická hodnota pevnosti (meze kluzu) konstrukčních materiálů, jako je beton nebo ocel, ve skutečnosti odpovídá pravděpodobnosti nižší než $5 \%$, která se uvádí v EN 1990 [2]. Tato skutečnost vzniká snahou o zvýšení jakosti výroby materiálů, která vede ke zvýšení průměru pevnosti skutečné produkce.

\section{Př́íklad uplatnění alternativních postupů podle ISO 13822}

Postup hodnocení spolehlivosti existujících konstrukcí je ukázán na př́kladu porušených balkónových nosníků panelových domů v severní části ČR. Kloknerův ústav se zúčastnil prohlídek 230 balkónů o stáří přibližně 45 let (použit konstrukční systém T0-6B-BTS). Vizuální prohlídka ukázala, že výztuž železobetonových nosníků byla na mnohých místech silně zkorodovaná vlivem porušené izolace. Karbonatace betonů se projevovala 
zejména $\mathrm{v}$ čelních partiích balkónů. Na základě průzkumu bylo zjištěno, že nosníky byly vyrobeny z betonu třídy $\mathrm{C} 16 / 20$ a výztuže $\mathrm{S} 200$ s průměrem $0,008 \mathrm{~m}$. Vyložení nosníků bylo $0,90 \mathrm{~m}$, jejich šířka $3,50 \mathrm{~m}$. Z výsledků průzkumu vyplynulo, že skutečná poloha výztuže se podstatně odlišovala od projektových předpokladů (navrženo krytí $0,01 \mathrm{~m}$, vzdálenost výztuže $0,15 \mathrm{~m}$ ). Pravděpodobnostní rozdělení krycí vrstvy výztuže $c$ pro celkem $n=$ 4890 měření ukazuje obr. 2. Skutečná tloušt'ka krycí vrstvy, která se mění od 0,002 do $0,065 \mathrm{~m}$, neposkytovala přiměřenou ochranu proti nepř́znivým účinkům prostředí a podstatně snižovala nosnou způsobilost balkónových nosníků. Jakost provedení prefabrikovaných nosníků byla velmi nízká.

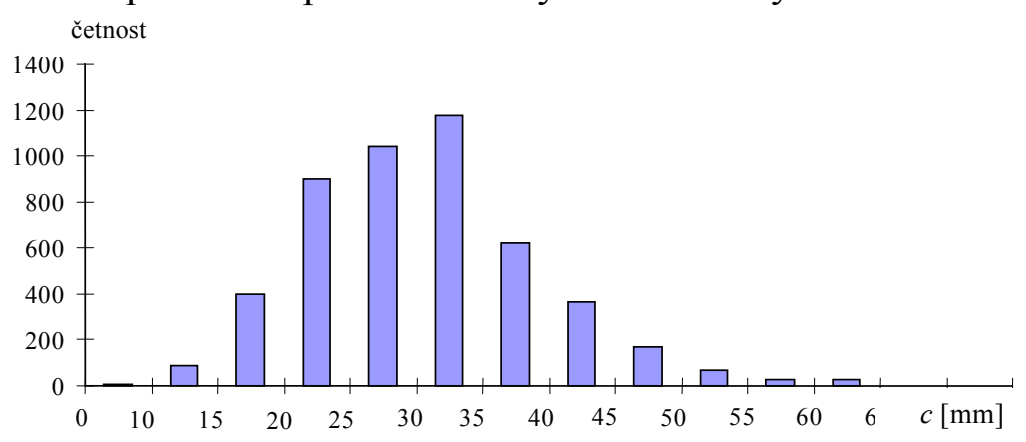

Obr. 2. Hustota pravděpodobnosti krycí vrstvy výztuže $c$ pro 230 balkónů (4890 měření, průměr krytí $\mu=0,026 \mathrm{~m}$, směrodatná odchylka $\sigma=0,009 \mathrm{~m}$, šikmost $\alpha=0,58$ )

\subsection{Ověření balkónových nosniků podle národních předpisů}

Z hodnocení nosníků metodou dílčích součinitelů podle ČSN 731201 [3] vyplývá, že návrhová odolnost nosníku $M_{R \mathrm{~d}}=6,0 \mathrm{kNm}$ je větší, než jsou návrhové účinky zatížení $M_{E \mathrm{~d}}=3,15 \mathrm{kNm}$ na $1 \mathrm{bm}$ nosníku. Pokud se však uvažuje redukce plochy výztuže vlivem koroze a její skutečná poloha, pak již podmínka $M_{R \mathrm{~d}}>M_{E \mathrm{~d}}$ nemusí být splněna. Na obr. 3 jsou uvedeny výsledky analýzy pro tři plochy výztuže $A_{\mathrm{s}}$ (pro návrhovou plochu $A_{\mathrm{s} 1}=$ $100 \%$ a pro redukované plochy $A_{\mathrm{s} 2}=90 \%$ a $A_{\mathrm{s} 3}=75 \%$ ). Na obrázku je také zachycena návrhová hodnota účinků zatížení $M_{E \mathrm{~d}}$.

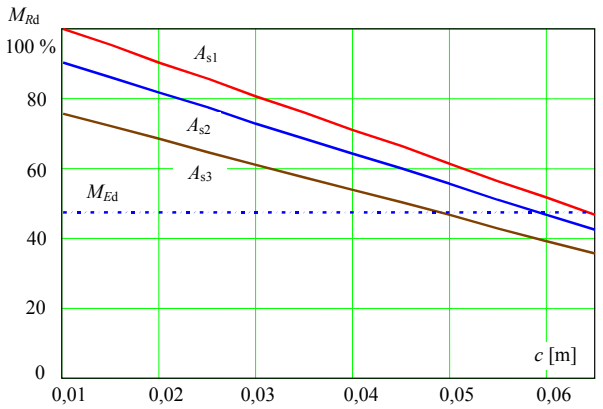

Obr. 3. Vliv zvyšující se krycí vrstvy výztuže $c$ na odolnosti $M_{R \mathrm{~d}}$ nosníku $\mathrm{v}$ procentech pro navrženou plochu výztuže $A_{\mathrm{s} 1}=100 \%$ a redukované plochy $A_{\mathrm{s} 2}=90 \%$ a $A_{\mathrm{s} 3}=75 \%$. 


\subsection{Pravděpodobnostní analýza spolehlivosti}

Pro analýzu spolehlivosti balkónových nosníků se použil pravděpodobnostní prŕstup podle ISO 13822 [1]. Uvažuje se následující funkce mezního stavu

$g=\theta_{R} n\left(\pi \phi^{2} / 4\right) f_{\mathrm{y}}\left[h-c-\phi / 2-0,5 n\left(\pi \phi^{2} / 4\right) f_{\mathrm{y}} / f_{\mathrm{c}}\right]-\theta_{E}(g+p) L^{2} / 2$

kde základní veličiny jsou uvedeny $\mathrm{v}$ tabulce 1 , včetně př́slušného typu pravděpodobnostního rozdělení. Pravděpodobnostní modely základních veličin byly stanoveny na základě pokynů př́ručky [4] mezinárodní výzkumné organizace JCSS a výsledků vyhodnocených zkoušek.

Vliv redukce plochy výztuže $\Delta A_{\mathrm{s}}$ na index spolehlivosti $\beta$ pro čtyři př́ípady tloušt'ky krycí vrstvy $c$ (podle vyhodnocení měření jednotlivých balkónů) je uveden na obr. 4. Významnou základní veličinou ovlivňující ukazatele spolehlivosti balkónových nosníků je krycí vrstva výztuže. Pokud se neuvažuje súbytkem plochy výztuže $\Delta A_{\mathrm{s}}$, pak se podle obr. 4 index $\beta$ snižuje od 5,2 do 3,7 pro zvyšující se krycí vrstvu $c$ od 0,01 do $0,03 \mathrm{~m}$.

Tab. 1 Pravděpodobnostní modely základních veličin

\begin{tabular}{|l|c|c|c|c|c|}
\hline Základní veličina & $\begin{array}{c}\text { Sym- } \\
\text { bol }\end{array}$ & $\begin{array}{c}\text { Rozdě- } \\
\text { lení }\end{array}$ & Rozměr & $\begin{array}{c}\text { Průměr } \\
\mu\end{array}$ & $\begin{array}{c}\text { Směrodatná } \\
\text { odchylka } \sigma\end{array}$ \\
\hline Pevnost betonu v tlaku & $f_{\mathrm{c}}$ & $\mathrm{LN}$ & $\mathrm{MPa}$ & 24 & 4 \\
Mez kluzu & $f_{\mathrm{y}}$ & $\mathrm{LN}$ & $\mathrm{MPa}$ & 240 & 15 \\
\hline Délka nosníku & $L$ & $\mathrm{DET}$ & $\mathrm{m}$ & 0,90 & - \\
Průměr výztuže & $\phi$ & $\mathrm{DET}$ & $\mathrm{m}$ & 0,008 & - \\
Počet prutů na balkón & $n$ & $\mathrm{DET}$ & - & 20 & - \\
Tl. balkónu ve vetknutí & $h$ & $\mathrm{LN}$ & $\mathrm{m}$ & 0,12 & 0,01 \\
Krycí vrstva & $c$ & $\mathrm{BET}$ & $\mathrm{m}$ & 0,026 & 0,009 \\
\hline Nejistota odolnosti & $\theta_{R}$ & $\mathrm{LN}$ & - & 1,1 & $0,05 \mu$ \\
Nejistoty účinku zatížení & $\theta_{E}$ & $\mathrm{LN}$ & - & 1 & 0,05 \\
\hline Obj. Tíha betonu & $\rho$ & $\mathrm{N}$ & $\mathrm{MN} / \mathrm{m}^{3}$ & nom. & 0,06 \\
Užitné zatížení & $p$ & $\mathrm{GAM}$ & $\mathrm{MN} / \mathrm{m}^{2}$ & 0,0008 & 0,00048 \\
\hline
\end{tabular}




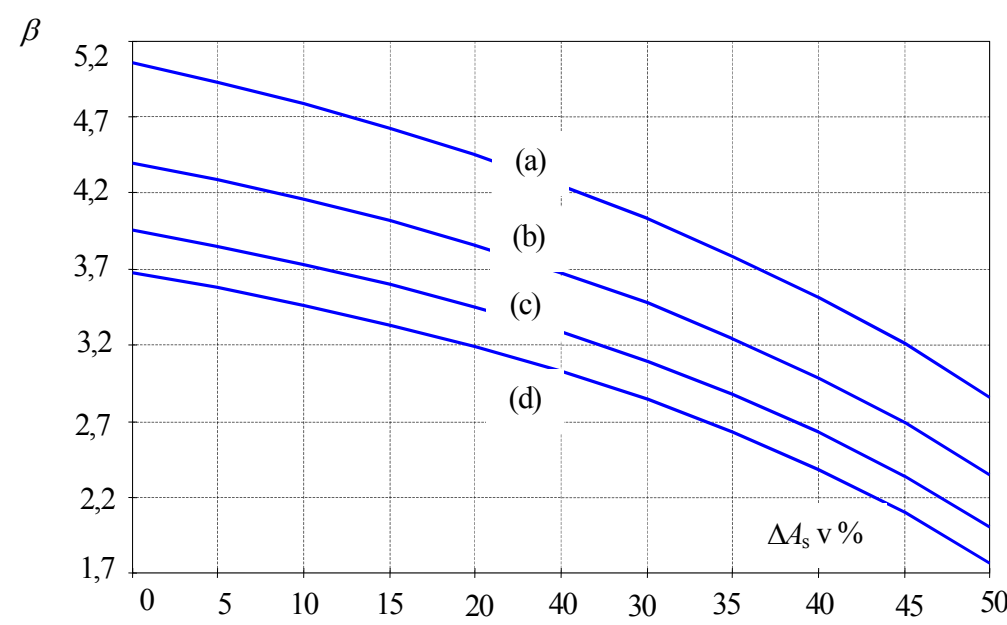

Obr. 4. Vliv redukce plochy výztuže $\Delta A_{\mathrm{s}}(\mathrm{v} \%)$ na index spolehlivosti $\beta$ pro čtyři prípady krycí vrstvy $c$ : (a) průměr $\mu=0,01 \mathrm{~m}$, (b) $0,02 \mathrm{~m}$, (c) $0,026 \mathrm{~m}$, (d) 0,03 m (variační koeficient $v=0,35$, dolní mez $a=0$, horní mez $b=3 \mu$, Beta rozdělení)

Původní návrh balkónových nosníků byl v souladu s požadavky tehdy platných ČSN. Nekvalitní vyrobení prefabrikovaných balkónových nosníků i dokončovací prováděcí práce vedly ke značné redukci plochy výztuže proti původním návrhovým předpokladům. Významnou základní veličinou ovlivňující ukazatele spolehlivosti balkónů je plocha výztuže a její krycí vrstva. Indexy spolehlivosti $\beta$ výrazně klesají se snižující se plochou výztuže vlivem koroze (index spolehlivosti $\beta$ se snížil asi na poloviční hodnotu při $50 \%$ úbytku plochy výztuže).

\section{Vliv dílčích součinitelů při hodnocení spolehlivosti}

Původní návrh balkónových nosníků byl ovlivněn hodnotami dílčích součinitelů a konstrukčními zásadami podle tehdy platných ČSN (dílčí součinitele pro stálá a proměnná zatížení $\gamma_{G}=1,1, \gamma_{Q}=1,3$, krytí výztuže $c=$ $0,01 \mathrm{~m})$. Eurokódy doporučují větší hodnoty dílčích součinitelů zatížení ( $\gamma_{G}$ $\left.=1,35, \gamma_{Q}=1,5\right)$ než ČSN. 


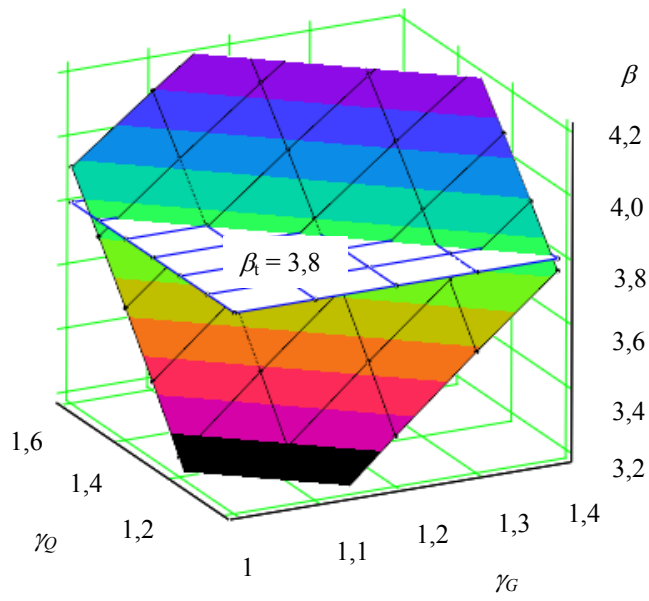

Obr. 4. Vliv dílčích součinitelů $\gamma_{G}$ a $\gamma_{Q}$ na úroveň spolehlivosti balkónových nosníků

\section{Závěrečné poznámky}

Mezinárodní norma ISO 13822 poskytuje návody pro hodnocení spolehlivosti existujících konstrukcí včetně možnosti aplikace pravděpodobnostních postupů. Pravděpodobnostní př́istupy podle této normy poskytují nové možnosti, jak rozhodnout o dalším používání existujících konstrukcí. Použití pravděpodobnostních metod pro hodnocení spolehlivosti existujících konstrukcí je uvedeno na příkladu balkónových nosníků. Přestože návrh nosníků splňoval požadavky tehdy platných předpisů, nízká jakost provedení a nepříznivé vlivy prostředí způsobily značné snížení spolehlivosti balkónů a vyvolaly potřebu jejich rekonstrukce. $\mathrm{Z}$ podrobného průzkumu a následného hodnocení bylo zjištěno, že se počáteční index spolehlivosti pohyboval u jednotlivých nosníkủ v rozmezí od 5,2 do 3,7. Když se uvážila redukovaná plocha výztuže způsobená korozí, index spolehlivosti dále významně poklesl.

Uznání Tato studie vznikla v Kloknerově ústavu ČVUT jako součást řešení projektu č. 103/06/1521 "Spolehlivost a hodnoceni rizik konstrukci v extrémnich podmínkách" podporovaného Grantovou agenturou $\check{C} R$.

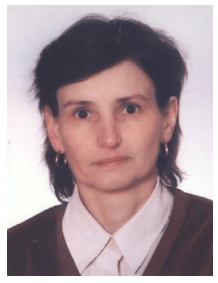

Doc. J. Markova is involved in the reliability analyses of structures, actions on structures, concrete structures, probabilistic methods of the theory of structural reliability, national and international standardisation activities. 